\title{
Harnessing Natural Mosaics: Antibody-Instructed, Multi-Envelope HIV-1 Vaccine Design
}

\author{
Robert E. Sealy ${ }^{1}$, Barry Dayton ${ }^{2}$, David Finkelstein ${ }^{3}$ and Julia L. Hurwitz ${ }^{1,4, *}$ \\ 1 Department of Infectious Diseases, St. Jude Children's Research Hospital, 262 Danny Thomas Place, \\ Memphis, TN 38105, USA; bob.sealy@stjude.org \\ 2 Department of Mathematics, Northeastern Illinois University, 5500 N. St Louis Ave, Chicago, IL 60625, USA; \\ bhdayton@neiu.edu \\ 3 Hartwell Center for Bioinformatics and Biotechnology, St. Jude Children's Research Hospital, 262 Danny \\ Thomas Place, Memphis, TN 38105, USA; David.finkelstein@stjude.org \\ 4 Department of Microbiology, Immunology and Biochemistry, University of Tennessee Health Science Center, \\ 858 Madison Avenue, Memphis, TN 38163, USA \\ * Correspondence: julia.hurwitz@stjude.org; Tel.: +1-901-595-2464
}

check for updates

Citation: Sealy, R.E.; Dayton, B.;

Finkelstein, D.; Hurwitz, J.L.

Harnessing Natural Mosaics:

Antibody-Instructed, Multi-Envelope

HIV-1 Vaccine Design. Viruses 2021,

13, 884. https://doi.org/10.3390/

v13050884

Academic Editor: Herve J. A. Fleury

Received: 1 March 2021

Accepted: 1 May 2021

Published: 11 May 2021

Publisher's Note: MDPI stays neutral with regard to jurisdictional claims in published maps and institutional affiliations.

\begin{abstract}
The year 2021 marks the 40th anniversary since physicians recognized symptoms of the acquired immunodeficiency syndrome (AIDS), a disease that has since caused more than 30 million deaths worldwide. Despite the passing of four decades, there remains no licensed vaccine for the human immunodeficiency virus type 1 (HIV-1), the etiologic agent of AIDS. Despite the development of outstanding anti-retroviral drugs, there are currently more than one-half million deaths each year due to AIDS. Here, we revisit a conventional vaccine strategy used for protection against variable pathogens like HIV-1, which combines an array of diverse surface antigens. The strategy uses antibody recognition patterns to categorize viruses and their surface antigens into groups. Then a leader is assigned for each group and group leaders are formulated into vaccine cocktails. The group leaders are 'natural mosaics', because they share one or more epitope(s) with each of the other group members. We encourage the application of this conventional approach to HIV-1 vaccine design. We suggest that the partnering of an antibody-instructed envelope cocktail with new vaccine vectors will yield a successful vaccine in the HIV-1 field.
\end{abstract}

Keywords: vaccines; protective immunity

\section{HIV-1 and the Lethal Disease of AIDS}

Human immunodeficiency virus type 1 (HIV-1) is the etiologic agent for acquired immunodeficiency syndrome (AIDS), the cause of a public health crisis that has killed approximately 33 million people worldwide. In the year 2019 alone, approximately 38 million people were infected with HIV-1 and approximately 690,000 people died. Effective anti-retroviral drugs have been developed and deployed, but these are not accessed by, or tolerated by, a large fraction of patients. In fact, AIDS-related deaths have been reduced by only $60 \%$ since peak deaths in 2004 [1,2]. Despite the passing of several decades since the discovery of HIV-1, there is no licensed vaccine.

\section{HIV-1 Vaccine Development-Advanced Clinical Studies}

The development of HIV-1 vaccines has followed a long and difficult course. The first vaccine to reach a phase III clinical study was developed by VaxGen Inc. Researchers studied two HIV-1 envelope gp120 proteins, selected to represent viral clades/subtypes of HIV-1 (based on virus sequences) that were common in the geographical regions where clinical studies were performed. No significant protection was observed in clinical studies with one or two gp120 envelope proteins [3-5].

In response to the failures with envelope-based vaccines, Merck later developed a vaccine that lacked an HIV-1 envelope. This vaccine included only internal proteins and 
was not designed to induce protective antibodies. In Merck's phase III study, there was no vaccine-induced protection [6,7].

The RV144 phase III study provided a hint of success [8]. This vaccine included a canary pox-based vector, ALVAC (expressing env, gag, and pol genes), plus two envelope proteins in alum. Using an intent-to-treat analysis of data, study leaders reported that protection was observed at a level of approximately $30 \%$ [8].

The more recent HIV- 1 vaccine phase III studies continue to focus on viral amino acid sequences and clades/subtypes for vaccine design. The Uhambo IIB/III (HVTN 702) study began in 2016 in South Africa and was sponsored by the National Institutes of Health (NIH), USA. One component of the vaccine was an ALVAC canarypox construct. Two additional components were clade/subtype $C$ gp120 envelope proteins formulated with an MF59 adjuvant. Clade/subtype $C$ was targeted, because of its high prevalence in South Africa. When data were evaluated, it was found that 129 HIV-1 infections occurred in the vaccinated group and $123 \mathrm{HIV}-1$ infections occurred in the placebo control group. Because the vaccine was found to be ineffective, after more than 5400 HIV-1-negative volunteers had been enrolled, NIH and its partners discontinued vaccinations $[3,9,10]$.

There are two large clinical studies ongoing, Imbokodo and Mosaico, supported by the Janssen Pharmaceutical Companies of Johnson \& Johnson and the NIH National Institute of Allergy and Infectious Diseases (NIAID). Each study involves the testing of computergenerated, sequence-based mosaics. Imbokodo (HPX2008/HVTN 705) is a Phase IIB study involving a prime-boost with a recombinant adenovirus (Ad26.Mos4.HIV, made by in silico combinations of $e n v, g a g$, and pol sequences) and a clade/subtype C gp140 envelope protein in adjuvant [3]. The study started in 2017 in southern African countries, finished enrollment of 2600 women in 2019, and is expected to close in 2022 [11,12]. Mosaico (HPX3002/HVTN 706) is a Phase III study designed to enroll approximately 3800 people across eight countries. The Mosaico vaccine components match those of the Imbokodo study, but additionally include a synthetic, sequence-based mosaic gp140 envelope protein. The study began in 2019 and may be completed in 2024 [13-15].

To date, the vaccines that have advanced to phase III clinical studies have each included less than a handful of different envelope proteins and have been designed with a focus on the viral amino acid sequences that are common in the geographical locations of the clinical studies. Hundreds of other vaccines have entered pre-clinical or phase I/II clinical studies [3,16-20]. Research has targeted a plethora of delivery vehicles and proteins, protein fragments, or peptides. Proteins have been generated from unmanipulated sequences, mutant sequences, computer generated sequence-based mosaics, consensus sequences, and ancestral sequences. Even a scrambled protein sequence, unlike any natural HIV-1 protein, was the focus of one HIV-1 vaccine program [21].

\section{Vaccine Successes against Other Diverse Pathogens}

HIV-1 is well known for the diversity of its envelope protein, the membrane protein responsible for binding virus to $\mathrm{CD} 4$ and other co-receptor molecules on the mammalian cell target. Lessons on how to design successful vaccines against diverse pathogens can be learned from successes in other fields. Routinely, when researchers target diverse pathogens, they use antibody recognition patterns to identify structurally distinct antigens on the pathogen's surface. For example, when Salk and his colleagues developed the polio vaccine in the mid-1900s, they used antibody reactivity patterns to identify viruses with similar or dissimilar epitopes. They then clustered viruses into three groups based on antibody reactivity patterns (each group included antigenically-similar viruses) and selected a representative from each group for formulation into a vaccine cocktail [22]. The rotavirus vaccine was similarly formulated and includes four components. The Prevnar-13 conjugate vaccine was similarly formulated and includes 13 components; newer pneumococcus vaccines are moving forward from Merck and Pfizer, with 15-valent and 20-valent cocktails, respectively [23]. The papillomavirus vaccine was similarly formulated and has 
nine components [24]. Each vaccine represents antigenically distinct pathogen variants and is used worldwide with an extraordinary positive influence on human health.

The immune system comprises B cells, T cells, and innate cells, with each contributing to protective responses against pathogens. $B$ cells and antibodies are often a focus of vaccine development, because when $B$ cells are appropriately triggered, their antibodies can persist lifelong in blood, lymph, and mucosal secretions [25]. When the pathogen initially contacts a host at the point of entry, antibodies serve as a first line of immune defense.

\section{Antibody-Instructed HIV-1 Vaccine Design}

Here, we consider the use of antibody-instructed cocktail vaccines for the prevention of HIV-1. The strategy is attractive, because: (i) antibodies are prominent defensive weapons against HIV-1 and (ii) many epitopes on viral proteins depend upon three- and four-dimensional (3D and 4D) structures. Epitopes bound by antibodies are hard to predict based on linear sequence alone (although predictions have been improved by recent advances in artificial intelligence [26,27]). When a single amino acid change occurs in a virus, it may be distant from a perceived epitope and may, at first glance, appear irrelevant to antibody binding. In fact, that one change may be sufficient to alter 3D and/or 4D protein structure and abolish antibody binding to a virus [28,29]. Antibody assays, unlike in silico predictions, provide direct evidence that an antibody recognizes its target.

The concept of designing antibody-instructed envelope cocktails is not new, but the value of these vaccines in the HIV-1 field has not yet been realized. Tests of antibodyinstructed HIV-1 envelope cocktails have generally been confined to settings of basic research or phase I clinical trials [17-20,30-36]. In past and present years, when HIV-1 research leaders have selected vaccines for advanced clinical trials, they have focused on envelope sequences and clades/subtypes more so than envelope antigenicity [11-15,37].

\section{Grouping HIV-1 Envelopes by Antigenicity-An Example of Virus/Envelope Selection}

An example of virus/envelope clustering based on antibody reactivity patterns is shown in Table 1. Clustering, in this case, was based on a small dataset described by Moore et al. [38]. Moore et al. had previously performed neutralization assays and reported the reciprocal $\mathrm{ID}_{50}$ values (serum dilutions required to neutralize virus at the $50 \%$ level) for $21 \mathrm{HIV}-1$ patient isolates with sera from the same patients. By focusing on a single assay, we avoided errors that could result by mixing data from dissimilar assays. In Table $1 \mathrm{~A}$ are the original reciprocal $\mathrm{ID}_{50}$ values. Viruses and their clades/subtypes are named in columns 1 and 2, respectively, while serum samples are listed on the top row. A score of 0 was given when no neutralization was detected, and a score of 256 was given when the reciprocal $\mathrm{ID}_{50}$ was greater than 128 . We used a strategy adapted from that of Smith et al. [39], which started with the ranking of data. When the score was 0 , the rank was 1 ; when the score was 8 or 16 , the rank was 2 ; when the score was 32 , the rank was 3 ; when the score was 64 or 128 , the rank was 4 ; when the score was 256 , the rank was 5 (Table 1B). The virus with the highest sum of ranked values (92ug001 virus) was assigned as a first leader (L1) for a first virus group (G1). For every other virus, the ranked value for each reciprocal $\mathrm{ID}_{50}$ score was subtracted from that of L1 to define distance (d), and the summed distance (sd) was determined. A maximum distance value (Dmax) was chosen (in this case Dmax = 20), and viruses with sd $\leq$ Dmax were assigned to G1 (indicating similarity of antibody reactivity patterns). Among remaining ungrouped viruses, the virus with the highest sd compared to L1 was selected as a second leader (L2, 92ug024), this time for group 2 (G2). New d and sd values were calculated as before for remaining viruses, this time based on L2 to assign viruses to G2. The process continued iteratively until all viruses were assigned to a group. Using the data in Table 1A and Dmax $=20$, the algorithm yielded seven groups (G1-G7) with respective leaders L1-L7 (Table 1B, leaders were 92ug001, 92ug024, 92th022, 92ug037, 92th024, 92th014, and 92rw008). Methods such as this can help researchers recognize viruses/envelopes with similar and disparate patterns of antibody recognition. 


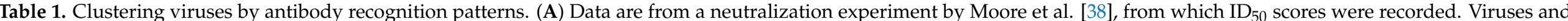

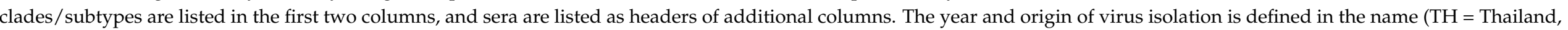

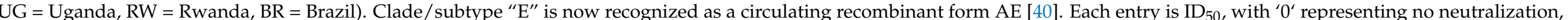

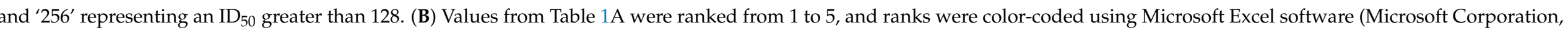

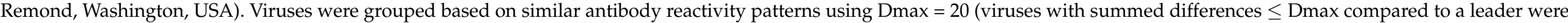
assigned to the same group). There were seven groups (separated by thick black lines) with respective leaders indicated at the top of each group in bold type.

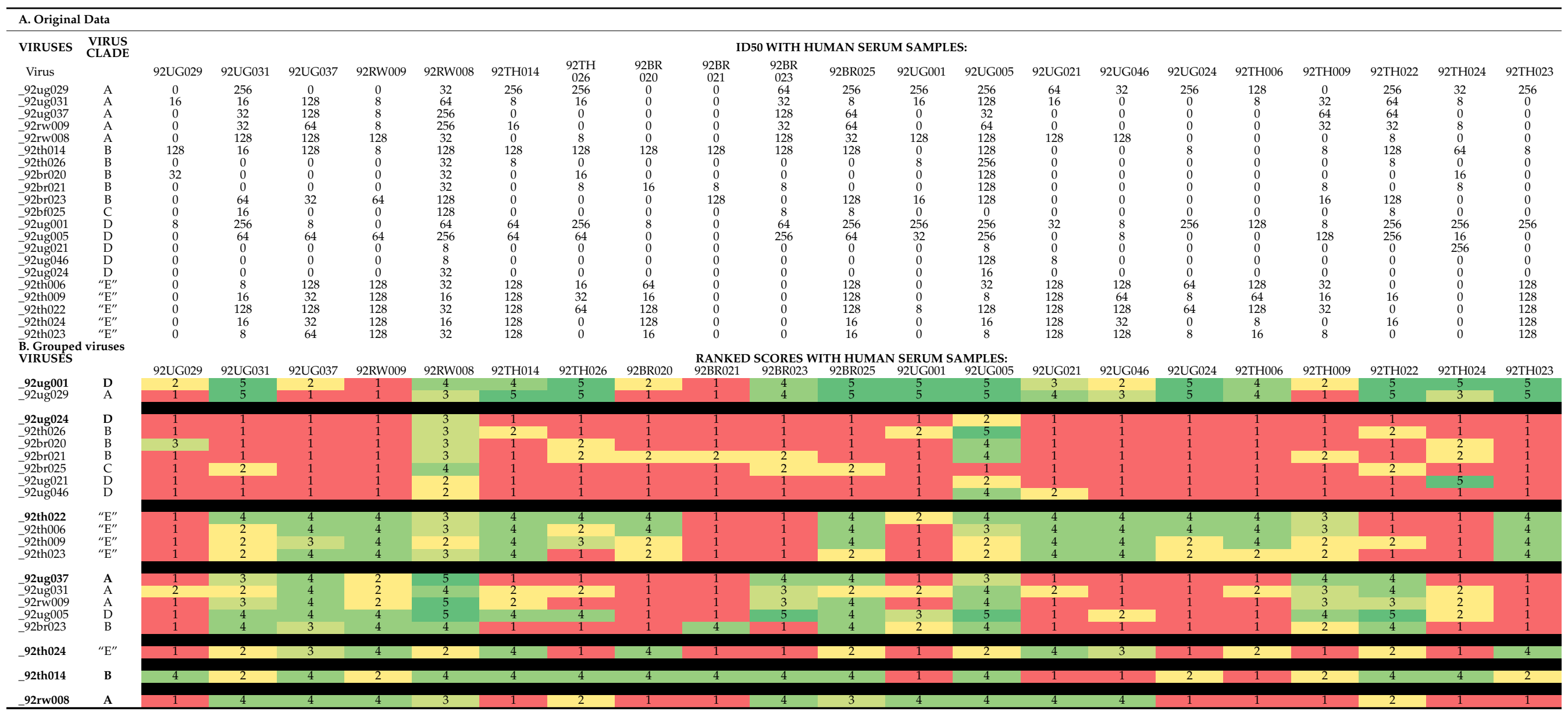


The leaders described here are 'natural mosaics' because they each contain a composite of epitopes that represent the other envelopes in their group. By using clustering algorithms such as this, and by selecting leaders for assembly, one may begin to create cocktails that represent the antigenic diversity of HIV-1.

How many envelopes can be formulated in a vaccine and recognized by the immune system? The immune system has, in fact, evolved a sophisticated mechanism of antibody production, whereby each developing B cell undergoes a unique gene rearrangement event. The number of unique antibodies that can be made in a human host, and the potential number of unique antigens that can be recognized, may easily exceed one trillion [41]. DNA library vaccines have been described in which thousands of antigens were introduced to the immune system simultaneously and elicited a protective immune response [42].

While a small $(21 \times 21)$ data matrix was used here, a matrix of any size could be examined for virus/envelope clustering. Mathematica computer code is provided in Supplementary Materials to support analyses of large datasets. There is a vast amount of antibody data in research literature, including data from high-throughput assays, that may assist the visualization of viral antigenic diversity and the design of comprehensive, antibody-instructed, HIV-1 envelope cocktails.

\section{Viruses and Antibody Reactivity Patterns Need Not Correlate with Geographical Location}

As previously described by Moore et al. [38], and pertinent to vaccine design, the geographical locations of viruses do not define their antibody reactivity patterns [43]. As shown in Table 1, viruses from Thailand often exhibited different antibody reactivity patterns amongst themselves, whereas viruses from different countries (Uganda, Rwanda, Brazil) could sometimes share patterns (Table 1B).

As an example, two viruses from Thailand, Th024 and TH014, were antigenically distinct. When serum samples were examined for neutralization of these two viruses, scores often differed by $\geq 2$ points in rank; four serum samples recognized Th024 better than Th014, and nine serum samples recognized Th014 better than Th024. If a vaccine were designed to include only one of these two viruses/envelopes, that vaccine would possibly fail to confer protection against the other. If, on the other hand, both viruses were represented in a vaccine cocktail, immune responses to each virus could be generated.

As another example, most serum samples showed discordant neutralization patterns for the two clade/subtype D viruses, UG005 and UG021. In this case, twelve serum samples recognized UG005 better than UG021, and one serum sample recognized UG021 better than UG005, each with a $\geq 2$-point difference in rank. Again, if a vaccine were designed to include only one of these two viruses/envelopes, the vaccine might fail to confer protection against the other.

Why might viruses within a country differ in antibody recognition patterns, while viruses from different countries share patterns? Immunodeficiency viruses are well known for their high mutation rates. When an individual is first infected with HIV-1, there may be limited viral diversity, but once an immune response is generated toward that virus, a circular evolutionary process begins. Antibodies may clear the founder virus from blood, but virus is maintained in privileged sites where it can generate escape mutants. New viruses induce new B cells and T cells, after which new escape mutants will emerge. Eventually, a plethora of viruses and virus-specific antibodies are present [44-47]. Because viruses are selected for envelopes that bind conserved mammalian CD4 and co-receptor molecules, shared envelope structures will appear repeatedly across hosts, countries, and clades/subtypes. In essence, a virus is constrained more by its functional requirements than by its geographical location [48]. It is for this reason that the co-evolution of viruses and antibodies in an untreated, infected individual can confer protective immunity against a viral infection from an outside source [7,8,47,49-59]. While the immune system might protect an individual from exogenous virus, it cannot clear endogenous virus from privileged sites (by definition). If the patient is untreated, the chronic virus infection destroys immune cells and eventually destroys the host. A critical aspect of successful vaccination is that 
the vaccine should be administered before, not after, a virus exposure, so that the immune system can eliminate the virus at its point of entry, prevent virus access to privileged sites, and thereby prevent chronic infection.

\section{Vaccine Development and Unanswered Questions}

\subsection{Which Assay Should Be Used to Cluster Viruses?}

Neutralization data were analyzed in Table 1, but was this the best choice? A clear correlate of protection against HIV-1 has not been defined, meaning that the 'best' assay for virus clustering remains a topic of debate. The neutralization assay is often favored, because antibodies are known to protect against immunodeficiency viruses [60-63] and because the assay measures functional effectors. Nonetheless, neutralization data must be viewed with caution, because protection in vivo does not always predict neutralization in vitro [64]. As an example, the weak protection afforded by the RV144 vaccine did not correlate with neutralization $[8,65]$. Some assay artifacts might be responsible, at least in part, for failed correlations. Various serum components can mediate non-specific virus kill in the neutralization assay [66]. There are also mutations and unexpected growth characteristics that may arise when viruses are propagated for the preparation of stocks or when chimeric pseudoviruses are used [67,68].

A second choice for use as a virus clustering assay is the enzyme-linked immunosorbent assay (ELISA). There are numerous additional choices to consider, given that virus transmits both by cell-free and cell-to-cell transmission, and that there is an extraordinary number of mechanisms by which antibodies inhibit viruses (e.g., antibody-dependent cellular cytotoxicity [ADCC], antibody-dependent cell-mediated virus inhibition [ADCVI]) [69-74].

Regardless of the assay chosen, standardization is essential. Attempts have been made to harmonize assays between laboratories [75], but this has not been accomplished globally. Harmonization is perhaps most critical when data are combined into banks (e.g., CATNAP [76]). Strict attention to data origin may help avoid misinterpretations and inaccurate virus comparisons.

\subsection{Which Antibody Source Should Be Used?}

In many vaccine fields, serum antibodies are used to identify virus groups. Human serum antibodies work well when a pathogen infection is acute, because each human sample will exhibit limited responsiveness. In HIV-1-infected patients, however, because of the chronic nature of infection, there is ongoing virus-antibody evolution as described above [46]. When serum antibodies are taken at a late stage of infection, they may recognize too many viruses to be useful for virus discrimination [36]. Perhaps a combination of monoclonal antibodies, patient sera, and polyclonal antibodies generated in research animals after controlled envelope immunizations will best serve as tools for antibodyinstructed HIV-1 envelope clustering [77].

\subsection{What Should Be the Dmax?}

The selection of Dmax must weigh many factors. As Dmax increases, the representation of antigenic diversity in a vaccine is diminished, a situation that can lead to pathogen escape from a vaccine-induced immune response [28,78,79]. As Dmax decreases, cocktails will increase in size, as will vaccine manufacturing and regulatory requirements. Presently, pneumococcus and papillomavirus vaccines are increasing in complexity, each with positive results $[23,24,80]$. New vaccine delivery vehicles are being developed that may simplify manufacturing logistics and support the development of complex cocktail vaccines, both within and outside of the HIV-1 field.

\subsection{Which Vaccine Delivery Vehicle Should Be Used?}

Once a cocktail is selected, what vaccine vehicle should be used? There have been dozens of delivery vehicles studied in the HIV-1 field, most of which can support the 
envelope cocktail approach. During the past year, mRNA vaccines have emerged as attractive delivery vehicles for severe acute respiratory syndrome coronavirus-2 (SARSCoV-2) vaccines $[81,82]$. mRNA vaccines might now facilitate HIV-1 vaccine development. The use of mRNA may simplify the logistics of cocktail vaccine development and thereby support an increase in cocktail complexity. mRNA vaccines are additionally attractive in that they, like live viral vaccines $[17,83-85]$, instruct the endogenous expression of antigens. Endogenous antigen expression, in turn, supports the robust activation of cytotoxic $\mathrm{T}$ lymphocytes (CTLs) that provide a fail-safe mechanism by clearing virus-infected cells if/when antibodies are not fully protective. The situation differs from that of subunit vaccines that require antigen cross-presentation to trigger CTLs [86,87] and that generally elicit relatively weak CTL responses. mRNA and live viral vaccines associate with durable immune responses that can persist for months, years, or decades $[17,25,88,89]$. Each of these qualities may increase the efficacy of an HIV-1 vaccine.

\subsection{Which Gatekeepers for Clinical Vaccine Development Should Be Used?}

Once a new HIV-1 vaccine candidate is designed, animal research studies can provide critical information about immunogenicity. The vaccination of small animals is a routine method for measuring the magnitude and quality of vaccine-induced $B$ cell and $T$ cell immune responses. A next step in HIV-1 vaccine development often involves the vaccination and challenge of non-human primates. Decades ago, chimpanzees were chosen for non-human primate experiments, because chimps were susceptible to HIV-1 infections. Today, challenges are usually performed in macaques. Instead of using HIV-1, scientists create chimeric viruses by combining sequences from HIV-1 and simian immunodeficiency viruses (SHIVs). Chimeras are then passaged repeatedly in monkeys to select for pathogenic strains [90]. SHIVs are not a perfect model for HIV-1 [47], and vaccines that successfully protect against SHIV challenges have failed in human clinical trials. By the same token, a vaccine that protects humans from HIV-1 might fail in a SHIV study. The question therefore remains open as to which gatekeeper is best for advancing HIV-1 vaccines to clinical trials.

\subsection{Vaccine Development in the Context of Unanswered Questions}

Many questions remain in the HIV-1 field that can easily stymy vaccine development. The situation is not unique, as every vaccine field must grapple with imperfect systems and unanswered questions. In the mid-1900s, Macfarlane Burnet, who later won a Nobel Prize for his discovery of clonal selection, contemplated that a successful polio vaccine might never be developed [91]. Soon thereafter, Salk and colleagues forged ahead despite unanswered questions, and with support from community leaders and the March of Dimes, developed a successful vaccine [92,93]. In the pneumococcus field, antibodyinstructed vaccines are constantly being questioned and improved, yet licensed vaccines continue to save lives. In the coronavirus disease 2019 (COVID-19) field, with intense public support despite unanswered questions, scientists demonstrated unprecedented speed in the development of SARS-CoV-2 vaccines $[81,82,89,94]$. Perhaps the time is opportune to accelerate activities in the HIV-1 research field, partner natural mosaics with novel vectors, and develop a vaccine that can prevent AIDS.

\section{Conclusions}

Our emphasis here is that multi-envelope vaccine design can be instructed by antibody reactivity patterns. Antibody-instructed vaccine cocktails have already succeeded in numerous fields. In the HIV-1 field, the partnering of new vectors (e.g., mRNA), data from antibody assays, and clustering algorithms might now expedite the design of a cocktail vaccine. A successful vaccine product may then be advanced to combat the ongoing public health crisis of HIV-1 and AIDS. 
Supplementary Materials: The following are available online at https:/ / www.mdpi.com/article/10 .3390/v13050884/s1

Author Contributions: Conceptualization, J.L.H.; methodology, R.E.S., B.D., D.F., J.L.H.; software, B.D.; validation, B.D., J.L.H.; investigation, R.E.S., B.D., D.F., J.L.H.; writing-original draft preparation, J.L.H.; writing-review and editing, R.E.S., B.D., D.F., J.L.H. All authors have read and agreed to the published version of the manuscript.

Funding: This research was funded by the NIH NCI P30 CA21765 and ALSAC.

Institutional Review Board Statement: Not applicable.

Informed Consent Statement: Not applicable.

Data Availability Statement: Not applicable.

Acknowledgments: This project was funded in part by the NIH NCI P30CA21765 and ALSAC.

Conflicts of Interest: The authors declare no conflict of interest.

\section{References}

1. Global HIV/AIDS Overview. Available online: https://www.hiv.gov/federal-response/pepfar-global-aids/global-hiv-aidsoverview (accessed on 7 May 2021).

2. Global HIV and AIDS statistics-2020 fact sheet. Available online: https://www.unaids.org/en/resources/fact-sheet (accessed on 28 February 2021).

3. Jones, L.D.; Moody, M.A.; Thompson, A.B. Innovations in HIV-1 Vaccine Design. Clin. Ther. 2020, 42, 499-514. [CrossRef] [PubMed]

4. Berman, P.W.; Gray, A.M.; Wrin, T.; Vennari, J.C.; Eastman, D.J.; Nakamura, G.R.; Francis, N.P.; Gorse, G.; Schwartz, D.H. Genetic and Immunologic Characterization of Viruses Infecting MN-rgp120-Vaccinated Volunteers. J. Infect. Dis. 1997, 176, 384-397. [CrossRef]

5. Adis Editorial. HIV gp120 Vaccine-VaxGen: AIDSVAX ${ }^{\mathrm{TM}}{ }^{\text {, AIDSVAX }}{ }^{\mathrm{TM}}$ B/B, AIDSVAX ${ }^{\mathrm{TM}}$ B/E, HIV gp120 Vaccine-Genentech, HIV gp120 Vaccine AIDSVAX_VaxGen, HIV Vaccine AIDSVAX_VaxGen. Drugs RED 2003, 4, 249-253. [CrossRef]

6. Robb, M.L. Failure of the Merck HIV vaccine: An uncertain step forward. Lancet 2008, 372, 1857-1858. [CrossRef]

7. HIV vaccine failure prompts Merck to halt trial. Nat. Cell Biol. 2007, 449, 390. [CrossRef]

8. Rerks-Ngarm, S.; Pitisuttithum, P.; Nitayaphan, S.; Kaewkungwal, J.; Chiu, J.; Paris, R.; Premsri, N.; Namwat, C.; De Souza, M.; Adams, E.; et al. Vaccination with ALVAC and AIDSVAX to Prevent HIV-1 Infection in Thailand. N. Engl. J. Med. 2009, 361, 2209-2220. [CrossRef] [PubMed]

9. Experimental HIV vaccine regimen ineffective in preventing HIV. Available online: https:/ /www.niaid.nih.gov/news-events/ experimental-hiv-vaccine-regimen-ineffective-preventing-hiv (accessed on 14 February 2021).

10. Cohen, J. Another HIV vaccine strategy fails in large-scale study. Science 2020. [CrossRef]

11. Clinical trials.gov. A study to assess the efficacy of a heterologous prime/boost vaccine regimen of Ad26.Mos4.HIV and aluminum phosphate-adjuvanted clade C gp140 in preventing human immunodeficiency virus (HIV) - 1 infection in women in sub-saharan Africa. Available online: https:/ / clinicaltrials.gov/ct2/show / NCT03060629 (accessed on 28 February 2021).

12. NIH and partners to launch HIV vaccine efficacy trial in the Americas and Europe. Available online: https://www.nih.gov/ news-events/news-releases/nih-partners-launch-hiv-vaccine-efficacy-trial-americas-europe (accessed on 28 February 2021).

13. A Study of Heterologous Vaccine Regimen of Adenovirus Serotype 26 Mosaic4 Human Immunodeficiency Virus(Ad26.Mos4.HIV), Adjuvanted Clade C gp140 and Mosaic gp140 to Prevent HIV-1 Infection Among Cis-gender Men and Transgender Individuals Who Have Sex With Cis-gender Men and/or Transgender Individuals (MOSAICO). 2021. Available online: https://clinicaltrials. gov/ct2/show / NCT03964415 (accessed on 7 May 2021).

14. Mega, E.R. 'Mosaic' HIV vaccine to be tested in thousands of people across the world. Nat. Cell Biol. 2019, 572, 165-166. [CrossRef]

15. Baden, L.R.; Stieh, D.J.; Sarnecki, M.; Walsh, S.R.; Tomaras, G.D.; Kublin, J.G.; McElrath, M.J.; Alter, G.; Ferrari, G.; Montefiori, D.; et al. Safety and immunogenicity of two heterologous HIV vaccine regimens in healthy, HIV-uninfected adults (TRAVERSE): A randomised, parallel-group, placebo-controlled, double-blind, phase 1/2a study. Lancet HIV 2020, 7, e688-e698. [CrossRef]

16. Hurwitz, J.L.; Lockey, T.D.; Jones, B.; Freiden, P.; Sealy, R.; Coleman, J.; Howlett, N.; Branum, K.; Slobod, K.S. First phase I clinical trial of an HIV-1 subtype D gp140 envelope protein vaccine: Immune activity induced in all study participants. AIDS 2008, 22, 149-151. [CrossRef] [PubMed]

17. Slobod, K.S.; Lockey, T.D.; Howlett, N.; Srinivas, R.V.; Rencher, S.D.; Freiden, P.J.; Doherty, P.C.; Hurwitz, J.L. Subcutaneous Administration of a Recombinant Vaccinia Virus Vaccine Expressing Multiple Envelopes of HIV-1. Eur. J. Clin. Microbiol. Infect. Dis. 2004, 23, 106-110. [CrossRef]

18. Sealy, R.; Slobod, K.S.; Flynn, P.; Branum, K.; Surman, S.; Jones, B.; Freiden, P.; Lockey, T.; Howlett, N.; Hurwitz, J.L. Preclinical and Clinical Development of a Multi-Envelope, DNA-Virus-Protein (D-V-P) HIV-1 Vaccine. Int. Rev. Immunol. 2009, 28, 49-68. [CrossRef] 
19. Gao, Y.; McKay, P.F.; Mann, J.F.S. Advances in HIV-1 Vaccine Development. Viruses 2018, 10, 167. [CrossRef]

20. Hurwitz, J.; Slobod, K.; Lockey, T.; Wang, S.; Chou, T.-H.; Lü, S. Application of the Polyvalent Approach to HIV-1 Vaccine Development. Curr. Drug Target Infect. Disord. 2005, 5, 143-156. [CrossRef] [PubMed]

21. Thomson, S.A.; Jaramillo, A.B.; Shoobridge, M.; Dunstan, K.J.; Everett, B.; Ranasinghe, C.; Kent, S.J.; Gao, K.; Medveckzy, J.; Ffrench, R.A.; et al. Development of a synthetic consensus sequence scrambled antigen HIV-1 vaccine designed for global use. Vaccine 2005, 23, 4647-4657. [CrossRef]

22. Bodian, D. Neutralization of Three Immunological Types of Poliomyelitis Virus by Human Gamma Globulin. Exp. Biol. Med. 1949, 72, 259-261. [CrossRef]

23. Hurley, D.; Griffin, C.; Young, M.; A Scott, D.; Pride, M.W.; Scully, I.L.; Ginis, J.; Severs, J.; Jansen, K.U.; Gruber, W.C.; et al. Safety, Tolerability, and Immunogenicity of a 20-Valent Pneumococcal Conjugate Vaccine (PCV20) in Adults 60 to 64 Years of Age. Clin. Infect. Dis. 2020. [CrossRef]

24. Yih, W.K.; Kulldorff, M.; Dashevsky, I.; Maro, J.C. A Broad Safety Assessment of the 9-Valent Human Papillomavirus Vaccine. Am. J. Epidemiology 2021. [CrossRef]

25. Hyland, L.; Sangster, M.; Sealy, R.; Coleclough, C. Respiratory virus infection of mice provokes a permanent humoral immune response. J. Virol. 1994, 68, 6083-6086. [CrossRef]

26. Senior, A.W.; Evans, R.; Jumper, J.; Kirkpatrick, J.; Sifre, L.; Green, T.; Qin, C.; Žídek, A.; Nelson, A.W.R.; Bridgland, A.; et al. Improved protein structure prediction using potentials from deep learning. Nature 2020, 577, 706-710. [CrossRef]

27. Service, R.F. 'The game has changed.' AI triumphs at protein folding. Science 2020, 370, 1144-1145. [CrossRef]

28. D'Costa, S.; Slobod, K.S.; Webster, R.G.; White, S.W.; Hurwitz, J.L. Structural Features of HIV Envelope Defined by Antibody Escape Mutant Analysis. AIDS Res. Hum. Retroviruses 2001, 17, 1205-1209. [CrossRef] [PubMed]

29. Gerhard, W.; Yewdell, J.W.; Frankel, M.E.; Webster, R.G. Antigenic structure of influenza virus haemagglutinin defined by hybridoma antibodies. Nat. Cell Biol. 1981, 290, 713-717. [CrossRef] [PubMed]

30. Zolla-Pazner, S.; Gorny, M.K.; Nyambi, P.N.; VanCott, T.C.; Nádas, A. Immunotyping of Human Immunodeficiency Virus Type 1 (HIV): An Approach to Immunologic Classification of HIV. J. Virol. 1999, 73, 4042-4051. [CrossRef]

31. Nyambi, P.N.; Nkengasong, J.; Lewi, P.; Andries, K.; Janssens, W.; Fransen, K.; Heyndrickx, L.; Piot, P.; Van Der Groen, G. Multivariate analysis of human immunodeficiency virus type 1 neutralization data. J. Virol. 1996, 70, 6235-6243. [CrossRef]

32. Jones, B.G.; Sealy, R.E.; Zhan, X.; Freiden, P.J.; Surman, S.L.; Blanchard, J.L.; Hurwitz, J.L. UV-inactivated vaccinia virus (VV) in a multi-envelope DNA-VV-protein (DVP) HIV-1 vaccine protects macaques from lethal challenge with heterologous SHIV. Vaccine 2012, 30, 3188-3195. [CrossRef]

33. Zhan, X.; Martin, L.N.; Slobod, K.S.; Coleclough, C.; Lockey, T.D.; Brown, S.A.; Stambas, J.; Bonsignori, M.; Sealy, R.E.; Blanchard, J.L.; et al. Multi-envelope HIV-1 vaccine devoid of SIV components controls disease in macaques challenged with heterologous pathogenic SHIV. Vaccine 2005, 23, 5306-5320. [CrossRef]

34. Hurwitz, J.L.; Zhan, X.; Brown, S.A.; Bonsignori, M.; Stambas, J.; Lockey, T.D.; Sealy, R.; Surman, S.; Freiden, P.; Jones, B.; et al HIV-1 vaccine development: Tackling virus diversity with a multi-envelope cocktail. Front. Biosci. 2008, 13, 609-620. [CrossRef] [PubMed]

35. Lockey, T.D.; Slobod, K.S.; Caver, T.E.; D'Costa, S.; Owens, R.J.; McClure, H.M.; Compans, R.; Hurwitz, J.L. Multi-Envelope HIV Vaccine Safety and Immunogenicity in Small Animals and Chimpanzees. Immunol. Res. 2000, 21, 7-22. [CrossRef]

36. Hurwitz, J.L.; Bonsignori, M. Multi-Envelope HIV-1 Vaccine Development: Two Targeted Immune Pathways, One Desired Protective Outcome. Viral Immunol. 2018, 31, 124-132. [CrossRef]

37. Gray, G.E.; Bekker, L.-G.; Laher, F.; Malahleha, M.; Allen, M.; Moodie, Z.; Grunenberg, N.; Huang, Y.; Grove, D.; Prigmore, B.; et al. Vaccine Efficacy of ALVAC-HIV and Bivalent Subtype C gp120-MF59 in Adults. N. Engl. J. Med. 2021, 384, 1089-1100. [CrossRef]

38. Moore, J.P.; Cao, Y.; Leu, J.; Qin, L.; Korber, B.; Ho, D.D. Inter- and intraclade neutralization of human immunodeficiency virus type 1: Genetic clades do not correspond to neutralization serotypes but partially correspond to gp120 antigenic serotypes. J. Virol. 1996, 70, 427-444. [CrossRef]

39. Smith, D.J.; Lapedes, A.S.; De Jong, J.C.; Bestebroer, T.M.; Rimmelzwaan, G.F.; Osterhaus, A.D.M.E.; Fouchier, R.A.M. Mapping the Antigenic and Genetic Evolution of Influenza Virus. Science 2004, 305, 371-376. [CrossRef] [PubMed]

40. Hraber, P.; Korber, B.T.; Lapedes, A.S.; Bailer, R.T.; Seaman, M.S.; Gao, H.; Greene, K.M.; McCutchan, F.; Williamson, C.; Kim, J.H.; et al. Impact of Clade, Geography, and Age of the Epidemic on HIV-1 Neutralization by Antibodies. J. Virol. 2014, 88, 12623-12643. [CrossRef] [PubMed]

41. Li, Z.; Woo, C.J.; Iglesias-Ussel, M.D.; Ronai, D.; Scharff, M.D. The generation of antibody diversity through somatic hypermutation and class switch recombination. Genes Dev. 2004, 18, 1-11. [CrossRef] [PubMed]

42. Smooker, P.M.; Setiady, Y.Y.; Rainczuk, A.; Spithill, T.W. Expression library immunization protects mice against a challenge with virulent rodent malaria. Vaccine 2000, 18, 2533-2540. [CrossRef]

43. Slobod, K.S.; Coleclough, C.; A Brown, S.; Stambas, J.; Zhan, X.; Surman, S.; Jones, B.G.; Zirkel, A.; Freiden, P.J.; Brown, B.; et al. Clade, Country and Region-specific HIV-1 Vaccines: Are they necessary? AIDS Res. Ther. 2005, 2, 3. [CrossRef] [PubMed]

44. Scheid, J.F.; Mouquet, H.; Feldhahn, N.; Seaman, M.S.; Velinzon, K.; Pietzsch, J.; Ott, R.G.; Anthony, R.M.; Zebroski, H.; Hurley, A.; et al. Broad diversity of neutralizing antibodies isolated from memory B cells in HIV-infected individuals. Nat. Cell Biol. 2009, 458, 636-640. [CrossRef] 
45. Richman, D.D.; Wrin, T.; Little, S.J.; Petropoulos, C.J. Rapid evolution of the neutralizing antibody response to HIV type 1 infection. Proc. Natl. Acad. Sci. USA 2003, 100, 4144-4149. [CrossRef]

46. Wrin, T.; Crawford, L.; Sawyer, L.; Weber, P.; Sheppard, H.W.; Hanson, C.V. Neutralizing antibody responses to autologous and heterologous isolates of human immunodeficiency virus. JAIDS J. Acquir. Immune Defic. Syndr. 1994, 7, 211.

47. Rencher, S.D.; Slobod, K.S.; Dawson, D.H.; Lockey, T.D.; Hurwitz, J.L. Does the Key to a Successful HIV Type 1 Vaccine Lie among the Envelope Sequences of Infected Individuals? AIDS Res. Hum. Retroviruses 1995, 11, 1131-1133. [CrossRef] [PubMed]

48. Weber, J.; Fenyö, E.M.; Beddows, S.; Kaleebu, P.; Björndal, A. Neutralization serotypes of human immunodeficiency virus type 1 field isolates are not predicted by genetic subtype. The WHO Network for HIV Isolation and Characterization. J. Virol. 1996, 70, 7827-7832. [CrossRef] [PubMed]

49. Cranage, M.; Whatmore, A.; Sharpe, S.; Cook, N.; Polyanskaya, N.; Leech, S.; Smith, J.; Rud, E.; Dennis, M.; Hall, G. Macaques Infected with Live Attenuated SIVmac Are Protected against Superinfection via the Rectal Mucosa. Virology 1997, 229, 143-154. [CrossRef]

50. Gonzales, M.J.; Delwart, E.; Rhee, S.; Tsui, R.; Zolopa, A.R.; Taylor, J.; Shafer, R.W. Lack of Detectable Human Immunodeficiency Virus Type 1 Superinfection during 1072 Person-Years of Observation. J. Infect. Dis. 2003, 188, 397-405. [CrossRef]

51. Ronen, K.; McCoy, C.O.; Matsen, F.A.; Boyd, D.F.; Emery, S.; Odem-Davis, K.; Jaoko, W.; Mandaliya, K.; McClelland, R.S.; Richardson, B.A.; et al. HIV-1 Superinfection Occurs Less Frequently Than Initial Infection in a Cohort of High-Risk Kenyan Women. PLOS Pathog. 2013, 9, e1003593. [CrossRef]

52. Sealy, R.; Zhan, X.; Lockey, T.D.; Martin, L.; Blanchard, J.; Traina-Dorge, V.; Hurwitz, J.L. SHIV infection protects against heterologous pathogenic SHIV challenge in macaques: A gold-standard for HIV-1 vaccine development? Curr. HIV Res. 2009, 7, 497-503. [CrossRef]

53. A Sharpe, S.; Whatmore, A.M.; Cranage, M.P.; A Hall, G. Macaques infected with attenuated simian immunodeficiency virus resist superinfection with virulence-revertant virus. J. Gen. Virol. 1997, 78, 1923-1927. [CrossRef] [PubMed]

54. Titti, F.; Di Fabio, S.; Amadori, A.; Monardo, F.; Verani, P.; Maggiorella, M.T.; Sernicola, L.; Panzini, G.; Koanga-Mogtomo, M.; Zamarchi, R.; et al. Live attenuated simian immunodeficiency virus prevents super-infection by cloned SIVmac251 in cynomolgus monkeys. J. Gen. Virol. 1997, 78, 2529-2539. [CrossRef]

55. Tsui, R.; Herring, B.L.; Barbour, J.D.; Grant, R.M.; Bacchetti, P.; Kral, A.; Edlin, B.R.; Delwart, E.L. Human Immunodeficiency Virus Type 1 Superinfection Was Not Detected following 215 Years of Injection Drug User Exposure. J. Virol. 2004, 78, 94-103. [CrossRef] [PubMed]

56. E Clements, J.; Montelaro, R.C.; Zink, M.C.; Amedee, A.M.; Miller, S.; Trichel, A.M.; Jagerski, B.; Hauer, D.; Martin, L.N.; Bohm, R.P. Cross-protective immune responses induced in rhesus macaques by immunization with attenuated macrophage-tropic simian immunodeficiency virus. J. Virol. 1995, 69, 2737-2744. [CrossRef] [PubMed]

57. Daniel, M.D.; Kirchhoff, F.; Czajak, S.C.; Sehgal, P.K.; Desrosiers, R.C. Protective effects of a live attenuated SIV vaccine with a deletion in the nef gene. Science 1992, 258, 1938-1941. [CrossRef] [PubMed]

58. Chakraborty, B.; Valer, L.; De, M.C.; Soriano, V.; Quinones-Mateu, M.E. Failure to detect human immunodeficiency virus type 1 superinfection in $28 \mathrm{HIV}$-seroconcordant individuals with high risk of reexposure to the virus. AIDS Res. Hum. Retroviruses 2004, 20, 1026-1031. [CrossRef] [PubMed]

59. Stephens, E.B.; Joag, S.V.; Atkinson, B.; Sahni, M.; Li, Z.; Foresman, L.; Adany, I.; Narayan, O. Infected Macaques That Controlled Replication of SIVmacor Nonpathogenic SHIV Developed Sterilizing Resistance against Pathogenic SHIVKU-1. Virology 1997, 234, 328-339. [CrossRef]

60. Ruprecht, R.M.; Ferrantelli, F.; Kitabwalla, M.; Xu, W.; McClure, H.M. Antibody protection: Passive immunization of neonates against oral AIDS virus challenge. Vaccine 2003, 21, 3370-3373. [CrossRef]

61. Prince, A.M.; Reesink, H.; Pascual, D.; Horowitz, B.; Hewlett, I.; Murthy, K.K.; Cobb, K.E.; Eichberg, J.W. Prevention of HIV Infection by Passive Immunization with HIV Immunoglobulin. AIDS Res. Hum. Retroviruses 1991, 7, 971-973. [CrossRef]

62. Mascola, J.R. Passive transfer studies to elucidate the role of antibody-mediated protection against HIV-1. Vaccine 2002, 20, 1922-1925. [CrossRef]

63. Van Rompay, K.K.A.; Berardi, C.J.; Dillard-Telm, S.; Tarara, R.P.; Canfield, N.R.; Valverde, C.R.; Montefiori, D.C.; Cole, K.S.; Montelaro, R.C.; Miller, C.J.; et al. Passive immunization of newborn rhesus macaques prevents oral simian immunodeficiency virus infection. J. Infect. Dis. 1998, 177, 1247-1259. [CrossRef] [PubMed]

64. Bures, R.; Gaitan, A.; Zhu, T.; Graziosi, C.; McGrath, K.M.; Tartaglia, J.; Caudrelier, P.; El Habib, R.; Klein, M.; Lazzarin, A.; et al. Immunization with Recombinant Canarypox Vectors Expressing Membrane-Anchored Glycoprotein 120 Followed by Glycoprotein 160 Boosting Fails to Generate Antibodies That Neutralize R5 Primary Isolates of Human Immunodeficiency Virus Type 1. AIDS Res. Hum. Retroviruses 2000, 16, 2019-2035. [CrossRef] [PubMed]

65. Kim, J.H.; Excler, J.-L.; Michael, N.L. Lessons from the RV144 Thai Phase III HIV-1 Vaccine Trial and the Search for Correlates of Protection. Annu. Rev. Med. 2015, 66, 423-437. [CrossRef] [PubMed]

66. Hosoi, S.; Borsos, T.; Dunlop, N.; Nara, P.L. Heat-labile, complement-like factor(s) of animal sera prevent(s) HIV-1 infectivity in vitro. J. Acquir. Immunodefic. Syndr. 1990, 3, 366-371.

67. Layne, S.P.; Merges, M.J.; Spouge, J.L.; Dembo, M.; Nara, P.L. Blocking of human immunodeficiency virus infection depends on cell density and viral stock age. J. Virol. 1991, 65, 3293-3300. [CrossRef] [PubMed] 
68. Louder, M.K.; Sambor, A.; Chertova, E.; Hunte, T.; Barrett, S.; Ojong, F.; Sanders-Buell, E.; Zolla-Pazner, S.; McCutchan, F.E.; Roser, J.D.; et al. HIV-1 envelope pseudotyped viral vectors and infectious molecular clones expressing the same envelope glycoprotein have a similar neutralization phenotype, but culture in peripheral blood mononuclear cells is associated with decreased neutralization sensitivity. J. Virol. 2005, 339, 226-238. [CrossRef]

69. Bonsignori, M.; Pollara, J.; Moody, M.A.; Alpert, M.D.; Chen, X.; Hwang, K.-K.; Gilbert, P.B.; Huang, Y.; Gurley, T.C.; Kozink, D.M.; et al. Antibody-Dependent Cellular Cytotoxicity-Mediating Antibodies from an HIV-1 Vaccine Efficacy Trial Target Multiple Epitopes and Preferentially Use the VH1 Gene Family. J. Virol. 2012, 86, 11521-11532. [CrossRef]

70. Haynes, B.F.; Gilbert, P.B.; McElrath, M.J.; Zolla-Pazner, S.; Tomaras, G.D.; Alam, S.M.; Evans, D.T.; Montefiori, D.C.; Karnasuta, C.; Sutthent, R.; et al. Immune-Correlates Analysis of an HIV-1 Vaccine Efficacy Trial. N. Engl. J. Med. 2012, 366, 1275-1286. [CrossRef]

71. Li, S.S.; Gilbert, P.B.; Tomaras, G.D.; Kijak, G.; Ferrari, G.; Thomas, R.; Pyo, C.-W.; Zolla-Pazner, S.; Montefiori, D.; Liao, H.-X.; et al. FCGR2C polymorphisms associate with HIV-1 vaccine protection in RV144 trial. J. Clin. Investig. 2014, 124, 3879-3890. [CrossRef] [PubMed]

72. Malbec, M.; Porrot, F.; Rua, R.; Horwitz, J.; Klein, F.; Halper-Stromberg, A.; Scheid, J.F.; Eden, C.; Mouquet, H.; Nussenzweig, M.C.; et al. Broadly neutralizing antibodies that inhibit HIV-1 cell to cell transmission. J. Exp. Med. 2013, 210, 2813-2821. [CrossRef] [PubMed]

73. Mazurov, D.; Ilinskaya, A.; Heidecker, G.; Lloyd, P.; Derse, D. Quantitative Comparison of HTLV-1 and HIV-1 Cell-to-Cell Infection with New Replication Dependent Vectors. PLOS Pathog. 2010, 6, e1000788. [CrossRef] [PubMed]

74. Shunaeva, A.; Potashnikova, D.; Pichugin, A.; Mishina, A.; Filatov, A.; A Nikolaitchik, O.; Hu, W.-S.; Mazurov, D. Improvement of HIV-1 and Human T Cell Lymphotropic Virus Type 1 Replication-Dependent Vectors via Optimization of Reporter Gene Reconstitution and Modification with Intronic Short Hairpin RNA. J. Virol. 2015, 89, 10591-10601. [CrossRef]

75. Brown, B.K.; Darden, J.M.; Tovanabutra, S.; Oblander, T.; Frost, J.; Sanders-Buell, E.; De Souza, M.S.; Birx, D.L.; McCutchan, F.E.; Polonis, V.R. Biologic and Genetic Characterization of a Panel of 60 Human Immunodeficiency Virus Type 1 Isolates, Representing Clades A, B, C, D, CRF01_AE, and CRF02_AG, for the Development and Assessment of Candidate Vaccines. J. Virol. 2005, 79, 6089-6101. [CrossRef]

76. Yoon, H.; Macke, J.; West, A.P.; Foley, B.; Bjorkman, P.J.; Korber, B.; Yusim, K. CATNAP: A tool to compile, analyze and tally neutralizing antibody panels. Nucleic Acids Res. 2015, 43, W213-W219. [CrossRef] [PubMed]

77. Sealy, R.E.; Jones, B.G.; Surman, S.L.; Branum, K.; Howlett, N.M.; Flynn, P.M.; Hurwitz, J.L. Murine Monoclonal Antibodies for Antigenic Discrimination of HIV-1 Envelope Proteins. Viral Immunol. 2016, 29, 64-70. [CrossRef] [PubMed]

78. Brueggemann, A.B.; Pai, R.; Crook, D.W.; Beall, B. Vaccine Escape Recombinants Emerge after Pneumococcal Vaccination in the United States. PLOS Pathog. 2007, 3, e168. [CrossRef]

79. Palmu, A.A.; Kaijalainen, T.; Jokinen, J.; Kilpi, T.M. Efficacy of the 7-Valent Pneumococcal Conjugate Vaccine Against Acute Otitis Media Caused by Serotype 6C Pneumococcus. Pediatr. Infect. Dis. J. 2015, 34, 796-797. [CrossRef] [PubMed]

80. Petrosky, E.; Bocchini, J.A.; Hariri, S.; Chesson, H.; Curtis, C.R.; Saraiya, M.; Unger, E.R.; Markowitz, L.E. Use of 9-Valent Human Papillomavirus (HPV) Vaccine: Updated HPV Vaccination Recommendations of the Advisory Committee on Immunization Practices. MMWR. Morb. Mortal. Wkly. Rep. 2015, 64, 300-304. [PubMed]

81. Baden, L.R.; El Sahly, H.M.; Essink, B.; Kotloff, K.; Frey, S.; Novak, R.; Diemert, D.; Spector, S.A.; Rouphael, N.; Creech, C.B.; et al. Efficacy and Safety of the mRNA-1273 SARS-CoV-2 Vaccine. N. Engl. J. Med. 2020. [CrossRef]

82. Polack, F.P.; Thomas, S.J.; Kitchin, N.; Absalon, J.; Gurtman, A.; Lockhart, S.; Perez, J.L.; Marc, G.P.; Moreira, E.D.; Zerbini, C.; et al. Safety and Efficacy of the BNT162b2 mRNA Covid-19 Vaccine. N. Engl. J. Med. 2020, 383, 2603-2615. [CrossRef]

83. Chung, Y.H.; Beiss, V.; Fiering, S.N.; Steinmetz, N.F. COVID-19 Vaccine Frontrunners and Their Nanotechnology Design. ACS Nano 2020, 14, 12522-12537. [CrossRef] [PubMed]

84. Singh, R.; Kang, A.; Luo, X.; Jeyanathan, M.; Gillgrass, A.; Afkhami, S.; Xing, Z. COVID-19: Current knowledge in clinical features, immunological responses, and vaccine development. FASEB J. 2021, 35, e21409. [CrossRef]

85. Rawat, K.; Kumari, P.; Saha, L. COVID-19 vaccine: A recent update in pipeline vaccines, their design and development strategies. Eur. J. Pharmacol. 2021, 892, 173751. [CrossRef]

86. Bennett, S.R.; Carbone, F.R.; Karamalis, F.; Miller, J.F.; Heath, W.R. Induction of a CD8+ Cytotoxic T Lymphocyte Response by Cross-priming Requires Cognate CD4+ T Cell Help. J. Exp. Med. 1997, 186, 65-70. [CrossRef]

87. Brown, S.; Hurwitz, J.; Zhan, X.; Doherty, P.C.; Slobod, K. CD8+ T-cells: Are They Sufficient to Prevent, Contain or Eradicate HIV-1 Infection? Curr. Drug Target Infect. Disord. 2005, 5, 113-119. [CrossRef] [PubMed]

88. Crotty, S.; Felgner, P.; Davies, H.; Glidewell, J.; Villarreal, L.; Ahmed, R. Cutting Edge: Long-Term B Cell Memory in Humans after Smallpox Vaccination. J. Immunol. 2003, 171, 4969-4973. [CrossRef] [PubMed]

89. Widge, A.T.; Rouphael, N.G.; Jackson, L.A.; Anderson, E.J.; Roberts, P.C.; Makhene, M.; Chappell, J.D.; Denison, M.R.; Stevens, L.J.; Pruijssers, A.J.; et al. Durability of Responses after SARS-CoV-2 mRNA-1273 Vaccination. N. Engl. J. Med. 2021, 384, 80-82. [CrossRef]

90. A Reimann, K.; Li, J.T.; Veazey, R.; Halloran, M.; Park, I.W.; Karlsson, G.B.; Sodroski, J.; Letvin, N.L. A chimeric simian/human immunodeficiency virus expressing a primary patient human immunodeficiency virus type 1 isolate env causes an AIDS-like disease after in vivo passage in rhesus monkeys. J. Virol. 1996, 70, 6922-6928. [CrossRef] [PubMed]

91. Burnet, F.M. Poliomyelitis in the light of recent experimental work. Health Bull. 1945, 81, 2173-2177. 
92. Meldrum, M. “A calculated risk": The Salk polio vaccine field trials of 1954. BMJ 1998, 317, 1233-1236. [CrossRef]

93. Nathanson, N. David Bodian's contribution to the development of poliovirus vaccine. Am. J. Epidemiol. 2005, 161, 207-212. [CrossRef]

94. Walsh, E.E.; Frenck, R.W.; Falsey, A.R.; Kitchin, N.; Absalon, J.; Gurtman, A.; Lockhart, S.; Neuzil, K.; Mulligan, M.J.; Bailey, R.; et al. Safety and Immunogenicity of Two RNA-Based Covid-19 Vaccine Candidates. N. Engl. J. Med. 2020, 383, 2439-2450. [CrossRef] 